\title{
MODALITAS KALIMAT PADA ANTOLOGI CERITA PENDEK LUKISAN KALIGRAFI KARYA A. MUSTOFA BISRI
}

\author{
Ime ylda Afyolanda, Anita Widjajanti, dan Furoidatul Hus niah \\ Program Studi Pendidikan Bahasa dan Sastra Indonesia, FKIP, Universitas Jember \\ Jalan Kalimantan No. 37, Sumbersari, Jember 68121 \\ Surel: Imeyldaafy olanda@gmail.com
}

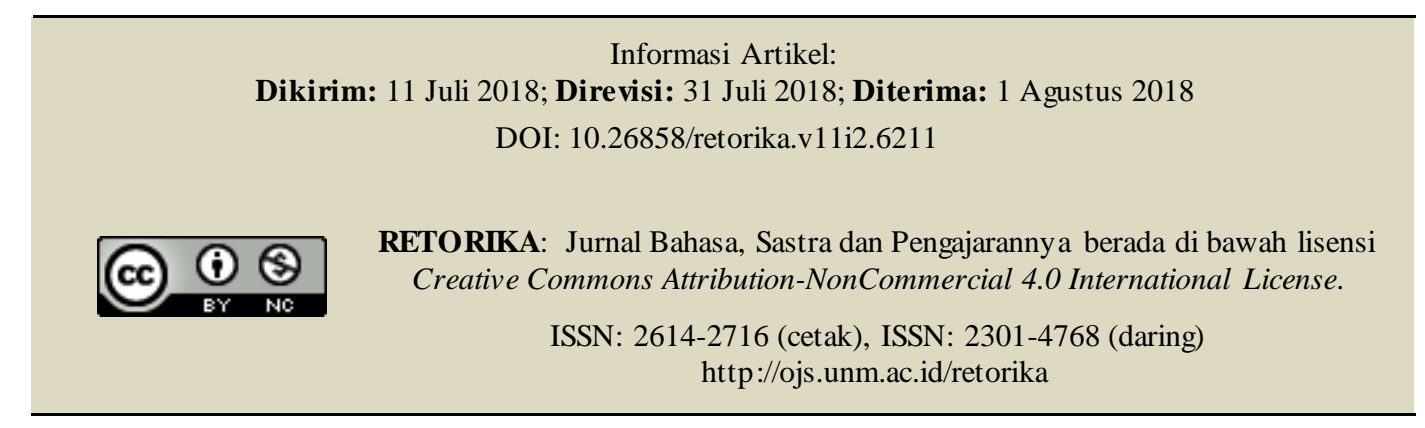

\begin{abstract}
Modality Sentence in Short Story Anthology Lukisan Kaligrafi By A. Mustofa Bisri. The aim of this research is to describe about modality sentence as a way to uncover A. Mustofa Bisri's style in short story anthology Lukisan Kaligrafi. This research uses descriptive qualitative research design. The results of this research are the types of modalities including intensional modality, epistemic modality, dynamic modality, and deontic modality. The functionality of modalities includes the function of changing the tone, expressing attitudes, and mood expression. Furthermore, modality as a learning alternative of short story text material for SMA class XI that focuses on characterizing short stories.
\end{abstract}

\begin{abstract}
Abstrak: Modalitas Kalimat Pada Antologi Cerita Pendek Lukisan Kaligrafi Karya A. Mustofa Bisri. Tujuan penelitian ini adalah mendeskripsikan mengenai modalitas kalimat untuk mengungkap gaya kepengarangan A. Mustofa Bisri pada antologi cerita pendek Lukisan Kaligrafi. Metode yang digunakan dalam penelitian ini adalah metode kualitatif deskriptif. Hasil penelitian adalah jenis-jenis modalitas, meliputi modalitas intensional, modalitas epis temik, modalitas dinamik, dan modalitas deontik. Fungsi modalitas, meliputi fungsi mengubah nada, menyatakan sikap, dan pengungkap suasana hati. Modalitas dapat digunakan sebagai alternatif materi pembelajaran teks cerita pendek untuk SMA difokuskan pada penokohan cerita pendek.
\end{abstract}

Kata kunci: cerpen, gaya pengarang, modalitas, Gus Mus 
Karya sastra merupakan sarana bagi setiap pengarang untuk mengungkapkan gagasan mengenai pengalaman batin yang menarik dan bersifat imajinatif. Karya sastra diciptakan untuk dinikmati, dipahami, dan dimanfaatkan dalam kehidupan. Hal ini sejalan dengan fungsi karya sastra, yaitu indah dan bermanfaat. Cerita pendek adalah salah satu bentuk karya sastra yang dimanfaatkan pembaca dalam kehidupan sehari-hari. Priyatni (2010:126) menyatakan bahwa cerita pendek merupakan salah satu bentuk karya fiksi yang memiliki sifat serba pendek baik dari segi isi, peristiwa yang diungkapkan, jumlah pelaku, dan jumlah kata yang digunakan.

Setiap pengarang memiliki style yang membedakan dengan pengarang lainnya. Salah satu pengarang yang menampilkan kekhasan bahasa dalam karyanya adalah A. Mustofa Bisri atau akrab disapa Gus Mus. Gus Mus dikenal pula sebagai ulama, pelukis, dan sastrawan. Cerpen karya Gus Mus dimuat di Harian Kompas. Selanjutnya, cerpen-cerpen tersebut dihimpun menjadi antologi dan diterbitkan dalam bentuk buku oleh penerbit Kompas dengan judul Lukisan Kaligrafi. Cetakan pertama terbit tahun 2003, cetakan kedua pada tahun 2005, cetakan ketiga terbit tahun 2008, dan cetakan keempat terbit pada tahun 2017.

Terdapat lima belas judul cerpen dalam antologi cerita pendek Lukisan Kaligrafi. Semua cerpen dalam antologi tersebut merefleksikan kehidupan manusia yang mencari hakikat hidup dari sisi spiritual. Kelima belas cerpen dalam antologi ini disajikan dengan bahasa yang sederhana dan merupakan bahasa percakapan sehari-hari. Hal ini sesuai dengan pendapat Chasanah (2005: 53) yang menyatakan bahwa Gus Mus melakukan eksplorasi narasi dan imaji dari lubuk batinnya dan mencari idiom estetik yang berkembang dalam atmosfer keulamaannya. Cara bertutur Gus Mus tidak mengada-ada, apa adanya, menjadi warna dan style penulisannya.

Gus Mus menghabiskan masa mudanya di pesantren dan menempuh jenjang perkuliahan di Universitas Al-Azhar Mesir. Oleh sebab itu, Gus Mus sangat paham mengenai dunia kaum santri yang diwujudkan dalam karya-karyanya. Daya tarik yang menonjol dari karya Gus adalah eksplorasi narasi dan imaji yang muncul dari dalam lubuk hati dan tak jauh dari latar belakang kehidupannya. Setiap kalimat yang diungkapkan mengandung keindahan. Pada penelitian ini, keindahan dalam antologi cerita pendek Lukisan $\mathrm{Ka}$ - ligrafi diungkap melalui salah satu unsur kebahasaan, yaitu penggunaan modalitas.

Modalitas menurut Sutedi (2004:93) adalah kategori gramatikal dalam kegiatan berkomunikasi yang digunakan penutur untuk mengungkapkan suatu sikap kepada mitra tutur, seperti menginformasikan, menyuruh, melarang, dan meminta. Modalitas kalimat dipilih sebagai topik penelitian karena melalui modalitas pembaca dapat mengetahui sikap pengarang yang dituangkan ke dalam tulisannya. Sikap ini mengenai suatu proposisi atau suatu peristiwa. Selain itu, modalitas juga memiliki kedudukan penting di dalam kalimat yang dapat mengubah makna kalimat. Modalitas juga dapat digunakan sebagai jalan mengungkap penokohan dan gaya kepengarangan atau style A. Mustofa Bisri.

Kebervariasian modalitas kalimat yang ada di dalam cerita menunjukkan kemampuan pengarang dalam memilih diksi dan menyatakan sikap. Hal ini menjadikan cerita tidak monoton dan membosankan ketika dibaca. Modalitas juga dapat digunakan sebagai pengungkap penokohan dan gaya kepengarangan atau style seorang pengarang. Oleh karena itu, modalitas kalimat dalam antologi cerita pendek sangat penting untuk diteliti.

Bagi pembelajaran bahasa Indonesia di sekolah, modalitas kalimat dapat menjadi salah satu alternatif materi pembelajaran pada teks cerpen di SMA kelas XI semester 1 untuk Kompetensi Dasar (KD) 3.9 Menganalisis unsur-unsur pembangun cerita pendek dalam buku kumpulan cerita pendek dan 4.9 Mengonstruksi sebuah cerita pendek dengan memerhatikan unsur-unsur pembangun cerita pendek. Unsur-unsur pembangun teks cerpen akan difokuskan pada penokohan cerpen. Di dalam buku bahasa Indonesia SMA/ MA/SMK/MAK kelas XI disebutkan bahwa penokohan dapat dianalisis melalui empat cara salah satunya melalui penggambaran tata kebahasaan tokoh. Modalitas yang digunakan tokoh dalam kalimat dapat mengungkap perwatakan berupa keraguan, keyakinan, kesangsian, dan kemauan.

Beberapa penelitian yang mengkaji modalitas dalam bahasa Indonesia telah dilakukan oleh peneliti sebelumnya. Prihantoro dan Fitriani (2015) mengkaji modalitas dalam teks berita online dan Jakfar Is (2016) mengkaji makna modalitas dalam kolom opini surat kabar. Berbeda dengan kedua penelitian tersebut yang menggunakan teks media massa sebagai objek kajian, penelitian ini menjadikan teks sastra sebagai objek. 
Menurut Eryon (2011) modalitas bersifat universitas sehingga berpotensi ada pada semua bahasa. Berdasarkan pandangan tersebut, puisi merupakan teks sastra yang memiliki karakteristik modalitas yang dipengaruhi oleh gaya penulisnya.

Damayanti (2012) meneliti adverbia penanda modalitas dan novel karya Andrea Hirata. Berbeda dengan penelitian Damayanti, penelitian ini bertujuan mengkaji teks puisi. Dengan demikian, hasil-hasil penelitian dapat saling melengkapi terkait penggunaan modalitas pada beragam jenis teks.

Berdasarkan uraian sebelumnya, penelitian ini bertujuan mengungkap (1) jenis-jenis modalitas (2) fungsi modalitas, dan (3) pemanfaatan modalitas pada antologi cerita pendek Lukisan Kaligrafi karya A. Mustofa Bisri. Hasil penelitian diharapkan memberikan temuan tentang gaya kepengarangan penulis.

\section{METODE}

Penelitian ini menggunakan rancangan kualitatif. Jenis penelitian merupakan penelitian deskriptif. Data penelitian berupa kalimat yang mengindikasikan modalitas. Sumber data berupa antologi cerita pendek Lukisan Kaligrafi karya A. Mustofa Bisri cetakan keempat tahun 2017 yang diterbitkan oleh Penerbit Kompas.

Metode pengumpul data yang digunakan dalam penelitian ini adalah metode dokumentasi. Metode analisis data yang digunakan, yaitu metode analisis isi. Langkah-langkah metode analisis isi dalam penelitian ini adalah (1) merumuskan pertanyaan penelitian, (2) melakukan sampling pada sumber data yang sudah dipilih, (3) membuat daftar kategori yang digunakan dalam analisis, (4) pengkodean pada data yang terpilih, dan (5) interpretasi atau penafsiran data.

Instrumen penelitian mencangkup instrumen utama dan instrumen pendukung. Instrumen utama, yaitu peneiti dan instrumen pendukung berupa tabel pengumpul data dan tabel analisis data. Prosedur penelitian terdiri atas tiga tahap, yaitu (1) tahap persiapan, (2) tahap pelaksanaan, dan (3) tahap penyelesaian.

\section{HASIL DAN PEMBAHASAN}

\section{Hasil}

Bagian hasil ini dibagi menjadi tiga bagian, yaitu jenis-jenis modalitas, fungsi modalitas kalimat, dan pemanfaatan modalitas sebagai salah satu alternatif materi pembelajaran bahasa Indonesia.

\section{Jenis Modalitas Kalimat pada Antologi Cerita Pendek Lukis an Kaligrafi}

Modalitas kalimat pada antologi cerita pendek Lukisan Kaligrafi karya A. Mustofa Bisri terdapat empat jenis, yaitu modalitas intensional, modalitas epistemik, modalitas deontik, dan modalitas dinamik. Paparan temuan jenis modalitas tersebut diuraikan sebagai berikut.

\section{Modalitas Intensional}

Modalitas intensional pada antologi cerita pendek Lukisan Kaligrafi dibagi menjadi empat makna, yaitu modalitas intensional bermakna 'keinginan', bermakna 'harapan', bermakna 'ajakan', bermakna 'pembiaran', dan bermakna 'permintaan'.

\section{Modalitas Intensional Bermakna 'Keinginan'}

Sikap yang dibahas dalam modalitas intensional bermakna 'keinginan', yaitu sikap penutur terhadap suatu peristiwa nonaktual yang diungkapkan secara tidak langsung. Modalitas intensional bermakna 'keinginan' dibagi menjadi empat kadar yaitu kadar 'keinginan', 'kemauan' dan 'maksud', serta 'keakanan'.

Modalitas intensional bermakna 'keinginan' berkadar 'keinginan'. Sikap penutur terhadap peristiwa nonaktual juga menjadi fokus pada modalitas intensional bermakna 'keinginan' berkadar 'keinginan'. Berikut data tentang modalitas tersebut.

(1) Tapi sejujurnya, sudah lama aku ingin berduaan saja dengannya.

(Bisri, 2017:50)

Data (1) merupakan modalitas intensional bermakna 'keinginan' berkadar 'keinginan' yang diungkap dengan kata ingin. Ingin diidentifikasi sebagai penanda modalitas intensional bermakna 'keinginan' berkadar 'keinginan' sebab mengacu pada keinginan penutur untuk berduaan bersama dengannya, yaitu seorang perempuan cantik yang disukainya. Sikap penutur yang ingin berduaan saja dengan perempuan pujaan hatinya berkaitan dengan peristiwa nonaktual atau belum terjadi dengan peluang terjadinya peristiwa yang belum bisa ditebak. 
Pengungkap ingin yang digunakan dalam modalitas intensional bermakna 'keinginan' berkadar 'keinginan' merupakan salah satu style Gus Mus sebagai seorang pengarang. Keindahan modalitas ingin, yaitu mampu menyampaikan isi pikiran tokoh. Pikiran dan perasaan yang dapat diekspresikan ke dalam suatu bentuk bahasa secara tepat dapat menimbulkan efek estetis. Pengungkap ingin menggambarkan tokoh cerita yang ingin berduaan dengan lawan jenis, tetapi tetap berusaha untuk tidak melampaui larangan agama.

Modalitas intensional bermakna 'keinginan' berkadar 'kemauan' dan 'maksud'. Kedua kadar dalam modalitas intensional bermakna 'keingianan' sulit dibedakan tetapi keberadaannya saling mendukung makna kalimat. Dikategorikan berkadar 'kemauan' apabila topik kalimat sudah disebutkan sebelumnya, sedangkan kadar 'maksud' berkaitan dengan peristiwa yang akan datang dan bersifat dinamis. Berikut ini data mengenai modalitas intensional bermakna 'keinginan' berkadar 'kemauan' dan 'maksud'.

(2) Maka dengan diam-diam dan tanpa pamit siapa-siapa, saya pun pergi ke tempat yang ditunjukkan ayah dalam mimpi dengan niat bilbarakah dan menimba ilmu beliau. (Bisri, 2017:5)

Pada data (2) terdapat penanda niat sebagai pengungkap modalitas intensional bermakna ' $\mathrm{ke}$ inginan' berkadar 'kemauan' dan 'maksud'. Dikategorikan sebagai modalitas intensional bermakna 'keinginan' berkadar 'kemauan' dan 'maksud' sebab pengungkap ini menggambarkan sikap penutur yang bertujuan untuk mencari ilmu dan berkah dari Allah. Hal ini berhubungan dengan peristiwa yang akan dilakukan dan bersifat dinamis dan topik pembicaraan sudah disebutkan sebelumnya.

Niat seringkali merujuk pada kegiatan keagamaan. Kreativitas Gus Mus menggunakan modalitas intensional bermakna 'keinginan' berkadar 'kemauan' dan 'maksud' sebagai cara meyakinkan pembaca bahwa niat sudah pasti dimotivasi oleh 'kemauan' dan 'maksud' untuk melakukan sesuatu. Penggunaan pengungkap niat menjadi penguat bagi kata berikutnya, yaitu bilbarakah. Jika diartikan, diksi niat bilbarakah menunjukkan kemauan dan maksud tokoh untuk mencari ilmu dengan tujuan mencari keberhakan ilmu dari Allah. Pengungkap niat menunjukkan bahwa Gus Mus memotivasi pembaca untuk mencari ilmu dengan ikhlas dan diniati karena Allah. Gus Mus mengajak pembaca untuk tidak sombong pada kegiatan yang berhubungan dengan akhirat sehingga pembaca bisa memetik pembelajaran tanpa merasa diperintah atau digurui.

Modalitas intensional bermakna 'keinginan' berkadar 'keakanan'. Waktu terjadinya peristiwa menjadi sudut pandang dalam modalitas intensional bermakna 'keinginan' berkadar 'keakanan'. Di bawah ini merupakan kutipan kalimat mengenai modalitas tersebut.

(3) "Jadi, tadinya Bapak hendak menulis Allah?" sela si bungsu.

(Bis ri, 2017:71)

Data (3) memiliki modalitas intensional bermakna 'keinginan' berkadar 'keakanan' yang diungkapkan dengan pengungkap hendak. Tokoh bapak awalnya hendak menulis lafaz Allah, tetapi cat yang tinggal sedikit dan waktu pengumpulan lukisan semakin dekat, akhirnya tokoh bapak hanya menulis huruf Alif. Tokoh bapak sudah mengaktualisasi keinginan untuk menulis huruf Alif meskipun hasilnya tidak sesuai dengan tujuan utamanya. Hendak merupakan modalitas intensional bermakna 'keinginan' berkadar 'keakanan' karena tokoh bapak melakukan perpindahan kegiatan dari kegiatan menulis Allah menjadi menulis huruf Alif.

Pengungkap hendak adalah gambaran penggunaan ungkapan bermakna konotatif yang baru dan asing bagi pembaca sebab pembaca lebih akrab dengan diksi akan daripada hendak. Gus Mus mengawinkan sisi linguistik sebagai bahasa sastra menggunakan modalitas. Salah satu cara mengawinkan linguistik dan keindahan bahasa sastra adalah dengan menggunakan pengungkap hendak sebab hendak tidak banyak digunakan.

Pengungkap hendak sebagai modalitas intensional bermakna 'keinginan' berkadar 'keakanan' merupakan pengungkap karakteristik bahasa sastra yang tidak mungkin mengulang-ulang bentuk yang sudah ada. Karakteristik bahasa sastra ini dapat ditinjau dari segi linguistik sehingga menyebabkan suatu karya sastra tidak bisa terlepas dari sisi linguistik. Bahasa dalam karya sastra boleh menggunakan bentuk-bentuk yang tidak lazim, tetapi harus dipertanggungjawabkan fungsinya sebagai salah satu komponen keindahan karya. 


\section{Modalitas Intensional Bermakna 'Harapan'}

Modalitas intensional bermakna 'harapan' ditandai oleh sikap penutur terhadap peristiwa nonaktual tak terkendali. Pengungkap modalitas ini dapat diwujudkan dalam bentuk verba dan adverbial. Berikut ini data yang mengandung pengungkap modalitas intensional bermakna 'harapan'.

(4) Seperti orang linglung, saya datangi surau itu dengan harapan bisa bertemu Kiai Tawakkal. (Bisri, 2017:12)

Data (4) menunjukkan modalitas intensionnal bermakna 'harapan' yang ditandai dengan pengungkap harapan. Pengungkap ini dikategorikan sebagai modalitas intensional bermakna 'harapan' sebab penutur tidak mampu mengendalikan terjadinya peristiwa sehingga penutur hanya berharap dapat bertemu dengan Kiai Tawakkal. Harapan dikategorikan sebagai modalitas intensional bermakna 'harapan' sebab penutur tidak mampu mengendalikan peristiwa sesuai keinginan dirinya sendiri.

Pengungkap harapan pada data tersebut dapat diganti dengan diksi lain, misalnya tujuan atau keinginan yang bermakna hampir sama dengan harapan. Gus Mus memilih pengungkap harapan daripada diksi lainnya sebab harapan lebih mengarah pada keinginan yang melibatkan campur tangan Tuhan. Hal ini menjadi tolak ukur keestetisan karya Gus Mus karena beliau setia menjaga hubungan antara dunia nyata dan imajinasi. Hubungan tersebut bisa ditelisik dari penggunaan harapan yang lebih mengarah pada keinginan yang berkaitan dengan situasi batin. Jadi, Gus Mus menjaga hubungan harapan antara manusia dengan Tuhan di dunia nyata dan di dunia fiksi dalam ceritanya.

\section{Modalitas Intensional Bermakna 'Ajakan'}

Modalitas intensional bermakna 'ajakan' menyatakan sikap penutur saat mengaktualisasi suatu peristiwa bersama mitra tutur. Modalitas intensional bermakna 'ajakan' dapat diikuti persona pertama tunggal atau persona pertama jamak tetapi tidak dapat diikuti oleh persona ketiga. Berikut ini merupakan data mengenai modalitas intensional bermakna 'ajakan'.

(5) “Ayo marilah kita duduk sebentar!" (Bisri, 2017:17)
Data (5) tersebut merupakan modalitas intensional bermakna 'ajakan' yang ditandai dengan sikap penutur kepada mitra tutur untuk mengaktualisasi suatu peristiwa bersama-sama. Penggunaan persona pertama jamak kita sebagai penekanan 'ajakan' merupakan penanda untuk mengaktualisasi suatu peristiwa bersama-sama.

Modalitas intensional bermakna 'ajakan' yang diungkapkan ayo marilah menggambarkan style kepengarangan Gus Mus. Beliau tidak taat terhadap kaidah gramatikal bahasa. Pengungkap ayo marilah merupakan penyimpangan kaidah gramatikal bahasa dalam karya sastra, tetapi tidak mengubah makna. Makna yang diungkapkan tetap sama, yaitu 'bersama-sama mengaktualisasi peristiwa'. Pengungkap ayo marilah seharusnya dipilih salah satu untuk mewakili makna 'ajakan' supaya tidak terjadi pemborosan kata. Gus Mus justru menabrak kaidah tersebut.

Saat orang lain diajak untuk melakukan sesuatu, Gus Mus tidak semena-mena dalam proses ajakan tersebut. Pengungkap ayo marilah merupakan gambaran sisi keulamaan Gus Mus yang santun dalam mengajak orang lain. Gus Mus mengajak pembaca untuk bersama-sama melakukan sesuatu tanpa merasa diperintah atau digurui.

\section{Modalitas Intensional Bermakna 'Pembiaran'}

Sikap penutur terhadap suatu peristiwa nonaktual yang diamati merupakan fokus utama modalitas intensional bermakna 'pembiaran'. Pelaku aktualisasi peristiwa dipilih oleh penutur. Penutur menilai sebaiknya yang menjadi pelaku aktualisasi peristiwa adalah penutur, mitra tutur, atau orang lain. Berikut ini data mengenai modalitas intensional bermakna 'pembiaran'.

(6) "Biarlah Mbah Joyo bercerita dulu." (Bisri, 2017:128)

Data (6) mengandung modalitas intensionnal bermakna 'pembiaran' sebab dalam kalimat tersebut penutur memutuskan membiarkan orang lain menjadi pelaku aktualisasi persitiwa. Mitra tutur dalam kutipan percakapan tersebut adalah beberapa orang yang baru datang dari beribadah haji. Sosok Mbah Joyo menghilang saat proses ibadah berlangsung. Ketika semua rombongan sampai di tenda, sosok Mbah Joyo sudah ada di dalam tenda. Penutur kemudian mengaktualisasi peristiwa dengan pengungkap biarlah untuk memberikan kesempatan kepada orang lain menjadi pelaku aktualisasi peristiwa. 
Pengungkap biarlah pada kalimat tersebut menunjukkan style Gus Mus, yaitu sederhana dan lugas. Selain itu, diksi yang digunakan juga tidak ambigu. Pengungkap biarlah memiliki makna, yaitu membiarkan orang lain melakukan sesuatu. Gus Mus memilih pengungkap denotatif dan tidak memilih diksi bermakna konotatif untuk mengungkapkan pembiaran kepada orang lain. Pembiaran justru diungkapkan dengan cara yang sopan. Gus Mus memudahkan pembaca untuk memaknai sebuah kalimat dan maksud yang ingin diungkapkan dengan penggunaan biarlah.

\section{Modalitas Intensional Bermakna 'Permintaan'}

Penutur sebagai orang yang memilih mitra tutur atau orang lain untuk melakukan sesuatu adalah ciri-ciri modalitas intensional bermakna 'permintaan'. Berikut ini data modalitas intensional yang bermakna 'permintaan'.

(7) Kasi kawan saya ini tempat sedikit! (Bisri, 2017:8)

Data (7) tersebut mengandung pengungkap kasi sebagai penanda modalitas intensional bermakna 'permintaan'. Kasi memiliki makna yang sama dengan tolong dan berikan. Kalimat tersebut menggambarkan sikap penutur agar mitra tutur melakukan sesuatu. Penutur memiliki kuasa memberi kesempatan bagi mitra tutur untuk mengaktualisasi peristiwa. Mitra tutur dapat memilih untuk melaksanakan atau tidak melaksanakan permintaan penutur karena mitra tutur juga memiliki kuasa untuk menolak atau tetap mengaktualisasi peristiwa yang diminta penutur.

Pada data tersebut, Gus Mus menghadirkan kreativitas pengucapan kata dengan memilih pengungkap kasi. Pemilihan ini menunjukkan penekanan pada keindahan auditif dan visual. Kebanyakan pengarang menggunakan diksi yang lazim dipakai dalam berbagai karya. Gus Mus memilih pengungkap kasi sebagai pembeda sebab diksi yang sering digunakan mengungkap 'pembiaran' adalah dengan diksi beri, berikan, dan kasih.

\section{Modalitas Epistemik}

Sikap yang dibahas dalam modalitas epistemic, yaitu keyakinan atau kekurangyakinan penutur terhadap peristiwa. Modalitas epistemik dibagi menjadi empat makna, yaitu bermakna 'kemungkinan', 'keteramalan', 'keharusan', dan 'kepastian'.

\section{Modalitas Epistemik Bermakna 'Kemungkinan'}

Penanda modalitas epistemik bermakna 'kemungkinan' digunakan oleh penutur untuk mengungkapkan pandangan atau penilaiannya terhadap suatu proposisi. Modalitas epistemik bermakna 'kemungkinan' ditandai oleh kadar restriksi dan kadar keinherenan yang rendah. Berikut data modalitas epistemik bermakna 'kemungkinan'.

(8) "Jangan-jangan ilmu beliau hilang pada saat beliau menghilang itu," komentar Mas Guru Slamet penuh penyesalan. (Bisri, 2017:3)

Data (8) mengandung modalitas epistemik bermakna 'kemungkinan' yang diungkapkan dengan pengungkap jangan-jangan. Pengungkap jangan-jangan menggambarkan kemungkinan yang terjadi pada orang lain di luar penutur dan mitra tutur. Ilmu yang dimaksud dalam kutipan percakapan di atas adalah ilmu kasyaf yang dimiliki tokoh Gus Jakfar. 'Kemungkinan' pada data (8) menggambarkan keadaan empiris antara hilangnya Gus Jakfar dan ilmu kasyaf-nya.

Pengungkap jangan-jangan pada data (8) dapat disubstitusikan dengan pengungkap lain yang bermakna sama, seperti mungkin dan barangkali. Pilihan pengungkap jangan-jangan menunjukkan pembaharuan dari sisi pengucapan daripada pengungkap lain yang sudah diungkap sebelumnya. Hal tersebut sesuai dengan kriteria keindahan bahasa dalam teks sastra yaitu tidak mengulang-ulang bentuk yang sudah ada. Gus Mus menonjolkan kreativitasnya dalam memilih dan mengolah diksi sehingga timbul banyak keindahan yang dapat ditangkap indra, baik secara auditif dan visual sehingga bisa menjadi daya tarik bagi pembaca.

\section{Modalitas Epistemik Bermakna 'Keteramalan'}

Makna 'keteramalan' dalam modalitas epistemik ini mencerminkan sikap penutur yang lebih, yakin terhadap suatu proposisi daripada sebelumnya. Berikut ini data modalitas epistemik bermakna 'keteramalan'.

(9) ... malah konon beberapa pejabat tinggi dari pusat memerlukan sowan khusus ke rumahnya setelah mengunjungi Kiai Saleh. (Bis ri, 2017:1)

Pada data (9) mengandung pengungkap konon sebagai penanda modalitas epistemik bermakna 'keteramalan'. Pengungkap modalitas $k o$ - 
non ini menunjukkan keyakinan penutur terhadap proposisi bahwa banyak pejabat tinggi yang sowan mengunjungi Kiai Saleh. Tingkat keepistemikan yang ditunjukkan dalam kalimat ini terletak pada fakta yang ditunjukkan penutur. Kesimpulan itu dibuat berdasarkan pandangan penutur bahwa kehormatan seorang kiai lebih tinggi daripada pejabat. Akhirnya, hukum alam tersebut, $k o$ non dikategorikan sebagai modalitas epistemik bermakna 'keteramalan'.

Gus Mus juga menggunakan pilihan kata sowan untuk merujuk kegiatan datang ke rumah seorang ulama. Penggunaan pengungkap bahasa Jawa ini memiliki fungsi tersendiri, yaitu sebagai acuan yang membedakan antara kunjungan ke rumah kalangan biasa dan kalangan ulama. Selain itu, sowan juga memiliki bentuk dan makna yang lebih singkat dan padat daripada pengungkap lainnya. Sowan juga merujuk pada latar belakang Gus Mus di dunia pesantren yang akrab dengan diksi sowan tersebut. Oleh sebab itu, letak keindahan cerita pada antologi cerita pendek $\mathrm{Lu}$ kisan Kaligrafi karya Gus Mus adalah perpaduan modalitas dan diksi bahasa Jawa yang difungsikan sebagai penguat cerita sehingga keindahan karya dan efek estetis karya tersebut tidak hilang.

\section{Modalitas Epistemik Bermakna 'Keharusan'}

Modalitas epistemik bermakna 'keharusan' adalah sikap penutur terhadap suatu proposisi yang tidak memiliki acuan atau noninferensial. Modalitas epistemik bermakna 'keharusan' memiliki fungsi sebagai keterangan keharusan untuk melakukan suatu tindakan. Berikut ini data modalitas epistemik bermakna 'keharusan'.

(10) Mestinya bulan syawal ini mereka menjadi segar kembali sebagai manusia seperti pemimpin agung mereka, Nabi Muhammad SAW yang selalu mencontohkan kasih-sayang kepada sekalian alam." (Bisri, 2017: 19)

Data (10) tersebut menunjukkan modalitas epistemik bermakna 'keharusan' yang ditandai dengan pengungkap mestinya. Kalimat tersebut mengindikasikan peluang yang dimiliki penutur sebagai sumber deontik. Sumber deontik yang dimaksud adalah kewenangan penutur untuk menyampaikan tuturan. Kalimat pada data (10) disampaikan oleh seorang ustad yang sudah biasa mengisi ceramah di berbagai tempat. Kewenangan yang ada dalam kalimat ini adalah kewajiban seorang ustad untuk mengingatkan dirinya sendiri dan orang lain.

Penutur lebih memiliki peluang sebagai sumber deontik dengan keberadaan pengungkap mestinya. Apabila pengungkap mestinya pada data (10) diganti dengan pengungkap patutnya, data (10) tidak menunjukkan kewenangan penutur yang berpeluang sebab penutur tidak bisa memberi kriteria patut dan tidak patut dalam bertindak. Pengungkap mestinya lebih berterima dan lebih bebas dimaknai daripada pengungkap modalitas epistemik bermakna 'keharusan' yang lainnya.

Pengungkap mestinya merupakan salah satu bentuk ragam bahasa resmi. Komponen ragam bahasa resmi pada antologi cerita pendek Lukisan Kaligrafi yang diberdayakan Gus Mus menjadi petunjuk adanya kebebasan memilih bentuk bahasa untuk digunakan dalam karya sastra. Pilihan tersebut menimbulkan efek estetis, yaitu pesan yang ingin disampaikan lebih mudah dipahami. Pesan pada data (10) yaitu keharusan manusia mencontoh Nabi Muhammad SAW dan bersikap mengasihi dan menyayangi satu sama lain.

\section{Modalitas Epistemik Bermakna 'Kepastian'}

Modalitas epistemik bermakna 'kepastian' memiliki tingkat keepistemikan paling tinggi di antara pengungkap modalitas epistemik lainnya. Makna 'kepastian' menggambarkan keyakinan penutur terhadap sebuah proposisi yang telah diungkapkannya. Modalitas epistemik bermakna 'kepastian' dapat digunakan secara sentensial dan tidak sentensial tergantung pada pengungkap 'kepastian' yang terdapat di dalam kalimat. Berikut ini data mengenai modalitas epistemik bermakna 'kepastian'.

(11) Anda pun pasti tak percaya: Kang Amin kawin dengan Nyai Jamilah, janda Kiai Nur. (Bis ri, 2017:78)

Data (11) tersebut mengandung pengungkap modalitas epistemik bermakna 'kepastian' yang diungkapkan pengungkap pasti. Pengungkap pasti pada data (11) menggambarkan keyakinan penutur terhadap ketidakpercayaan mitra tutur yang berada di sekitarnya bahwa Kang Amin menikahi janda Kiai Nur. Penutur sudah bisa memastikan bahwa mitra tutur akan terkejut saat mendengar bahwa Kang Amin ternyata sudah menikah dengan janda Kiai Nur. 
Penggunaan pengungkap pasti pada data (11) dirasa lebih sentensial daripada pengungkap pastilah. Pengungkap pasti bisa digunakan pada kalimat pernyataan maupun jawaban, sedangkan pastilah hanya bisa digunakan untuk kalimat pernyataan. Penggunaan pastilah menjadi tidak berterima apabila digunakan sebagai jawaban atas pertanyaan. Penutur sering menjawab pertanyaan yang mengindikasikan 'kepastian' menggunakan pengungkap tentu atau tentu saja, bukan menggunakan pastilah. Pastilah yang digunakan oleh mitra tutur untuk merespon penutur akan menjadikan jawaban mitra tutur, seperti memastikan kebenaran bukan menjawab pertanyaan.

Penggunaan diksi pasti sebagai pengungkap modalitas epistemik bermakna 'kepastian' dapat menggetarkan hati pembaca. Fungsi estetis dari penggunaan pasti ialah mampu mengungkapkan isi pikiran dan perasaan dengan tepat. Penutur memastikan bahwa mitra tutur pasti terkejut dengan pernyataannya bahwa Kang Amin telah menikahi janda Kiai Nur. Akhirnya, pengungkap pasti menunjukkan fungsi estetis dalam karya sastra sebagai pengungkap pikiran yang mampu menggetarkan dan mengejutkan hati pembaca.

\section{Modalitas Deontik}

Masalah yang dibahas dalam modalitas deontik mencakup dua hal utama, yaitu 'izin' dan 'perintah'. Modalitas deontik didasari dua kaidah, yaitu kaidah sosial dan kaidah resmi. Kaidah sosial dan kaidah resmi ini memengaruhi 'izin' dan 'perintah'. Kaidah sosial berhubungan dengan usia, tingkat sosial, dan kultur budaya, sedangkan kaidah resmi berhubungan dengan pendidikan dan pekerjaan. Berikut merupakan paparan data dari modalitas deontik bermakna 'izin' dan 'perintah'.

\section{Modalitas Deontik Bermakna 'Izin'}

Peran mitra tutur sebagai pelaku aktualisasi peristiwa menggambarkan ciri kepelakuan pada modalitas deontik bermakna 'izin'. Tolak ukur makna 'Izin' berasal dari adanya kaidah sosial dan kaidah resmi. Makna 'izin' juga menyoroti pandangan penutur mengenai tiga hal, meliputi keperluan terhadap tindakan, kemungkinan pelaksanaan, dan peran subjek dalam aktualisasi peristiwa sebagai pelaku. Berikut ini merupakan data dan pembahasan tentang modalitas deontik bermakna 'izin'.
(12) Sebentar lagi subuh. Setelah sembahyang subuh nanti, kau boleh pulang. (Bisri, 2017:12)

Data (12) tersebut dikategorikan sebagai kalimat yang mengandung modalitas deontik bermakna 'izin' karena yang bertindak sebagai penutur memiliki sumber kaidah sosial berupa kewenangan pribadi. Penutur pada data (12) merupakan seorang kiai yang memberi 'izin' kepada santrinya untuk pulang karena proses menimba ilmu sudah selesai. Mitra tutur sebagai pelaku aktualisasi peristiwa tidak mempunyai wewenang menolak 'izin' dari penutur dan harus melaksanakannya. Makna ‘izin' tersebut adalah penutur sebagai sumber deontik mengizinkan mitra tutur melakukan sesuatu. Oleh sebab itu, pengungkap modalitas deontik bermakna 'izin' pada data (12) harus diikuti verba. Verba yang mengikuti boleh pada data tersebut adalah pergi, merujuk kegiatan meninggalkan tempat yang sedang didiami.

Data (12) merupakan kalimat singkat, padat, dan tidak ambigu. Penutur mengizinkan mitra tutur untuk pergi setelah sembahyang subuh. Pengungkap boleh ini memberi kepuasan bagi mitra tutur karena penutur memperbolehkan pergi dengan cara yang sopan. Sesuai dengan nama penutur yaitu Kiai Tawakkal, tuturan yang diucapkannya juga mencerminkan kepribadian beliau yang tawadhu serta rendah hati.

Data (12) tersebut mencerminkan style kepengarangan Gus Mus, yaitu cara bertuturnya jelas dan tidak mengada-ada. Kiai Tawakkal mengizinkan santrinya pergi dengan cara yang tidak mengada-ada, sesuai apa adanya beliau. Gus Mus sebagai ulama dan pemimpin pesantren mampu menjaga hubungan fakta dan fiksi yaitu menjaga hubungan baik dengan orang lain, baik di dunia nyata ataupun di dunia fiksi, dengan tuturan yang santun sehingga mampu menyentuh pembaca.

\section{Modalitas Deontik Bermakna 'Perintah'}

Makna 'perintah' dapat dinyatakan dengan kalimat imperatif dan deklaratif, sedangkan makna 'izin' hanya dinyatakan dengan kalimat deklaratif. 'Perintah' dapat diartikan agar 'melakukan sesuatu' dan 'perintah untuk tidak melakukan sesuatu' atau biasa disebut sebagai larangan. Berikut data modalitas deontik bermakna 'perin-tah'.

(13) "Suatu malam saya bermimpi bertemu ayah dan disuruh mencari seorang wali sepuh..." (Bisri, 2017:5) 
Data (13) merupakan kalimat modalitas deontik bermakna 'perintah' dengan pengungkap disuruh. 'Perintah' yang diungkapkan melalui verba dengan prefiks $d i$ - pada kata disuruh mengiyaratkan bahwa yang menjadi sumber deontik bukan penutur melainkan orang lain di luar peristiwa tutur. Orang lain di luar peristiwa tutur adalah ayah dari penutur. Penutur sendiri berperan sebagai pelaku aktualisasi peristiwa. Ayah penutur menjadi sumber deontik sehingga perintahnya harus dipatuhi sang anak.

Pikiran penutur disampaikan secara tepat melalui pengungkap disuruh sebagai modalitas deontik bermakna 'perintah'. Gus Mus memilih aspek bahasa untuk menungkapkan perintah secara tepat. Hal ini mendapat penekanan sebab jika perintah tersebut tidak bisa disampaikan dengan jelas, maka penutur gagal mengutaran sikapnya terhadap suatu proposisi. Apabila penutur gagal, maka makna yang ditimbulkan dari penggunaan modalitas atau pengungkap perasaan dapat berubah menjadi ambigu.

Bagi pembaca yang suka mencari pesan dibalik sebuah cerita, hikmah yang dapat diambil, yaitu perintah dari orang tua harus dilaksanakan. Gus Mus mampu menjaga gaya tuturnya supaya tetap cair sehingga bisa menyentuh kedalaman hati pembaca. Style Gus Mus didapat melalui banyak cara salah satunya mengeksplorasi diksi. Ketepatan Gus Mus memilih diksi menunjukkan kreativitasnya memadukan jati dirinya sebagai ulama, ayah, dan pelaku aktualisasi peristiwa di dalam cerita. Hal tersebut kemudian mampu menarik pembaca dan ikut merasakan luapan perasaan dalam cerita yang ditulis Gus Mus.

\section{Modalitas Dinamik}

Karakteristik subjek dan keadaan yang memungkinkan subjek berperan sebagai pelaku aktualisasi peristiwa menjadi fokus utama dalam modalitas dinamik. Modalitas dinamik ini hanya memiliki satu makna, yaitu makna 'kemampuan'. Di bawah ini data dan pembahasan mengenai modalitas dinamik bermakna 'kemampuan'.

\section{Modalitas Dinamik Bermakna 'Kemampuan'}

Gambaran kebiasaan atau perbuatan yang dilakukan berulang-ulang merupakan hal utama yang dibahas pada modalitas dinamik bermakna 'kemampuan'. Modalitas ini melibatkan penutur dalam isi tuturan. Berikut ini data mengenai modalitas dinamik bermakna 'kemampuan'.
(14) Ah, bagaimana dia bisa mengucapkan pertanyaan itu dengan nada yang sama sekali biasa. (Bisri, 2017:52)

Data (14) memiliki pengungkap bisa sebagai penanda modalitas dinamik bermakna 'kemampuan'. Meskipun penutur tidak berperan sebagai pelaku aktualisasi peristiwa, namun penutur boleh mengemukakan suatu proposisi. Pengungkap 'kemampuan' memiliki tiga ciri, yaitu (a) subjek merupakan nomina bernyawa dan berperan sebagai pelaku; (b) verba digunakan untuk mengungkapkan perbuatan atau kegiatan fisik; (c) kemungkinan perbuatan itu dilakukan, ditentukan oleh subjek. Pada data (14), ciri-ciri pengungkap bagi modalitas deontik bermakna 'kemampuan' sudah sesuai dengan tiga ciri-ciri yang telah disebutkan. Ciri-ciri tersebut, yaitu (a) subjek berperan sebagai pelaku bernyawa yang mengaktualisasi peristiwa; (b) pengungkap verba berupa diungkapkan dengan kata mengucapkan; c) penutur tidak bertindak sebagai pelaku aktualisasi peristiwa. Mitra tutur diungkapkan secara langsung oleh penutur sebagai subjek aktualisasi peristiwa.

Penutur pada data (14) merupakan seseorang yang menyukai mitra tutur. Saat mitra tutur bertanya mengenai perasaannya dengan nada yang sangat biasa, penutur merasa terkejut dan gemas. Bisa sebagai pengungkap modalitas dinamik bermakna 'kemampuan' difungsikan sebagai penanda keindahan bahasa dalam teks sastra karena menyatakan kemampuan penutur yang bisa menjaga emosinya. Selain itu, data (14) mempunyai pola bunyi a sehingga dapat menggambarkan kreativitas pengucapan dan menibulkan efek merdu atau eufoni yang bisa mewakili perasaan bahagia penutur.

\section{Modalitas Bermakna Ganda}

Data sudah yang diungkapkan dan dibahas sebelumnya menunjukkan jenis-jenis modalitas pada antologi cerita pendek Lukisan Kaligrafi. Kalimat di dalam antologi tersebut tidak hanya mengandung satu modalitas tetapi bisa juga mengandung lebih dari satu modalitas yang bermakna berbeda. Berikut ini merupakan data yang mengandung lebih dari satu modalitas.

(15) Sebenarnya setelah makan, Haji Muin masih menahanku, ingin mengajak ngobrol, tapi setelah aku ingatkan tentang ibuku yang sendirian di rumah, dia memaklumi 
dan membiarkan aku pulang. (Bisri, 2017:119)

Data (15) mengandung satu jenis modalitas tetapi memiliki dua makna. Kedua makna tersebut masuk ke dalam modalitas intensional. Pengungkap ingin menunjukkan modalitas intensional bermakna 'keinginan' sedangkan membiarkan menunjukkan modalitas intensional bermakna 'pembiaran'. Penggunaan modalitas dalam kalimat yang memiliki lebih dari satu jenis atau satu fungsi. Kedua modalitas tersebut saling memenuhi fungsi masing-masing agar makna kalimat dapat diungkapkan secara lebih jelas dan tidak ambigu.

Fungsi estetis dari modalitas intensional bermakna 'keinginan' dan 'pembiaran' adalah sebagai media menyampaikan isi dan perasaan. Jika hanya satu pengungkap yang digunakan, maka pesan yang ingin disampaikan belum tentu tersampaikan seluruhnya. Sebagai contoh, jika menggunakan pengungkap 'pembiaran' saja, maka pesan yang diterima pembaca adalah penutur membiarkan mitra tutur untuk pulang. Jika menggunakan pengungkap 'keinginan', maka kalimat itu mengandung pesan mengenai keteguhan mempertahankan keinginan saja. Jadi, penggunaan kedua modalitas tersebut saling menopang makna kalimat.

\section{Fungsi Modalitas}

Fungsi modalitas kalimat adalah sebagai pengungkap sikap penutur terhadap peristiwa. Keberadaan modalitas sangat berperan penting dalam kalimat. Ada atau tidaknya modalitas memengaruhi makna sebuah kalimat. Selain itu, fungsi lain dari modalitas, yaitu (1) mengubah nada kalimat misalnya dari nada kasar menjadi lebih lembut atau sebaliknya, (2) menyatakan sikap dan tingkat keakraban berupa kepastian, penolakan, ajakan, perintah atau sikap lainnya, dan (3) pengungkap suasana hati berupa suasana indikatif, interogatif, imperatif, serta optatif. Fungsi lain modalitas dalam stilistika adalah sebagai pengungkap style kepengarangan Gus Mus. Semua fungsi modalitas sebagai salah satu komponen kebahasaan yang memenuhi fungsi estetis secara urut dipaparkan sebagai berikut.

\section{Mengubah Nada}

Modalitas berfungsi mengubah nada. Nada merupakan suatu bentuk penekanan pada sikap lembut, kasar, dan sikap lainnya yang diungkap melalui pemakaian modalitas. Berikut ini adalah paparan data mengenai modalitas yang berfungsi sebagai pengubah nada.

\section{(16) "Cobalah nakmas ikuti jalan setapak di sana itu" katanya. (Bisri, 2017:5)}

Data (16) mengandung modalitas bermakna 'perintah' yang diungkapkan dengan cobalah. Adanya pengungkap cobalah menjadikan nada kalimat lebih lembut, meskipun kalimat tersebut merupakan kalimat perintah. Kalimat tersebut dapat berubah menjadi kalimat bernada perintah yang tidak lembut apabila pengungkap cobalah dihilangkan. Makna kalimat tetap sama sebagai sebuah 'perintah' untuk mengikuti petunjuk yang diberikan oleh penutur, tetapi nada yang diterima mitra tutur dapat disesuaikan antara lembut dan sopan atau sebaliknya akibat adanya modalitas kalimat.

Perubahan nada kalimat dari nada kasar ke nada lembut atau sebaliknya dapat diungkap dalam antologi cerita pendek Lukisan Kaligrafi. Fungsi pengungkap cobalah adalah ekspresi pikiran yang diungkapkan melalui penggunaan bahasa. Modalitas mampu menjembatani pikiran dan kalimat yang dituturkan sehingga fungsi estetis bahasa sastra, yaitu mampu menyentuh dan memberi kepuasan batin dapat terwujud. Gus Mus sebagai sosok anutan memberikan jawaban atas banyak pertanyaan dengan nada yang sesuai dengan latar belakang dirinya sebagai muslim dan orang tua yaitu santun. Jadi, pembaca bisa menemukan sosok Gus Mus dapat teks yang ditulisnya.

\section{Menyatakan Sikap}

Modalitas kalimat dapat menyatakan sikap penutur terhadap suatu proposisi. Pada bagian ini, sikap yang dibahas hanya sikap kepastian yang diungkap penutur. Berikut merupakan data modalitas yang berfungsi menyatakan sikap.

(17) Kalaupun beliau keluar, biasanya untuk memenuhi undangan hajatan atau-dan ini sangat jarang sekali- mengisi pengajian umum. (Bisri, 2017:7)

Data (17) memiliki pengungkap sikap yang dinyatakan dengan sangat jarang sekali. Pengungkap sangat jarang sekali menunjukkan sikap kepastian yang dinyatakan dengan nada 
kepastian. Ketika penutur meyatakan sikapnya, penutur juga meyakini suatu proposisi. Penutur memastikan bahwa sosok beliau, yaitu Sang Kiai sangat jarang sekali keluar malam untuk datang ke pengajian umum dan hajatan. Penutur berani menyatakan sikap kepastian tanpa ada kata pasti tetapi kepastian ini diungkapkan dengan kalimat lain yang menyatakan sikap yang sama yaitu memastikan suatu proposisi itu benar.

Data (17) mencapai puncak keestetisan dengan adanya pengungkap modalitas sangat jarang sekali. Aspek kebahasaan diberdayakan dan merujuk pada keyakinan penutur sehingga memberi kepuasan bagi dirinya atas identifikasi yang telah penutur lakukan. Bentuk kepuasan yang ditimbulkan sebagai fungsi dan efek estetis modalitas pada data (17) adalah keyakinan penutur bahwa sosok Kiai yang sangat dihormati jarang sekali keluar mengisi pengajian pada waktu larut malam.

\section{Pengungkap Suasana Hati}

Modalitas sebagai pengungkap suasan hati yaitu penggunaan modalitas sebagai perwujudan luapan perasaan penutur. Fungsi pengungkap suasanan hati dibagi menjadi empat, yaitu fungsi indikatif, fungsi interogatif, fungsi imperatif, dan fungsi optatif. Fungsi-fungsi tersebut dipaparkan sebagai berikut.

\section{Fungsi Indikatif (Ketegasan)}

Fungsi indikatif atau ketegasan adalah fungsi modalitas yang memberi penekanan pada sikap penutur terhadap suatu proposisi. Sikap tersebut berupa sikap pernyataan, larangan. Di bawah ini data mengenai pengungkap modalitas yang berfungsi indikatif.

(18) Kau harus lebih berhati-hati bila mendapat cobaan dari Allah berupa anugerah. (Bisri, 2017:11)

Data (18) mengandung pengungkap harus sebagai penanda fungsi indikatif atau ketegasan modalitas. Harus berfungsi sebagai pengungkap suasana hati penutur yang ingin menegaskan bahwa cobaan dari Allah bukan hanya berupa musibah tetapi anugerah yang dimiliki manusia juga merupakan cobaan. Penutur menegaskan suatu proposisi kepada mitra tutur agar dirinya lebih hati-hati terhadap cobaan Allah.

Pengungkap harus menggambarkan style kepengarangan Gus Mus. Gaya tuturnya tidak melebih-lebihkan, sesuai dengan sosok Gus Mus yang sederhana dan cair. Data (18) merupakan cara Gus Mus berdakwah melalui tulisan agar manusia berhati-hati terhadap cobaan berupa kekurangan tetapi harus lebih waspada terhadap cobaan berupa kelebihan. Modalitas harus dalam data (18) merupakan cara Gus Mus menyentuh dan menggetarkan jiwa pembaca agar tidak takabur terhadap kelebihannya.

\section{Fungsi Introgatif (Pertanyaan)}

Fungsi introgratif atau fungsi pertanyaan adalah fungsi pengungkap modalitas untuk suatu keadaan yang membutuhkan jawaban. Berikut ini data dan pembahasan mengenai kalimat yang mengandung modalitas dengan fungsi sebagai pengungkap suasana hati pertanyaan atau fungsi interogatif.

(19) Sebagai kiai, apakah kau berani menjamin amalmu pasti mengantarmu ke sorga kelak? (Bisri, 2017:11)

Data (19) tersebut merupakan data yang mengandung penanda pasti sebagai pengungkap modalitas epistemik bermakna 'kepastian'. Pengungkap modalitas pasti adalah gambaran suasana hati penutur yang penasaran terhadap jawaban mitra tutur tentang kebenaran bahwa Allah menjamin kiai pasti masuk surga karena amalnya.

Penggunaan pengungkap pasti pada data (19) merupakan cara pengarang mengungkapkan pertanyaan untuk mencari jawaban. Jawaban dari pertanyaan tersebut adalah setiap manusia wajib berbuat baik tetapi tidak boleh sombong atas amal yang telah diperbuatnya. Pengungkap pasti dapat menimbulkan kesan keindahan dalam jiwa yang menjadi kepuasan saat ditangkap indra atau ditangkap pikiran dan hati. Kesan kemudian diubah menjadi pembelajaran serta pesan. Jadi, pengungkap modalitas pasti memenuhi fungsi ragam bahasa sastra yaitu menyentuh jiwa.

\section{Fungsi Imperatif (Perintah)}

Modalitas berfungsi sebagai pengungkap perintah atau imperatif, yaitu mengungkapkan suasana hati penutur yang memerintahkan untuk mengaktualisasi atau tidak mengaktualisasi suatu peristiwa. Berikut data modalitas yang berfungsi sebagai pengungkap suasana hati berupa perintah atau imperatif. 
(20) Nuruti orang tua, disuruh kawin sama anak orang kaya; baru tiga bulan kawin, sudah ditinggal kabur. (Bisri, 2017:43)

Data (20) menunjukkan pengungkap modalitas disuruh sebagai penanda suasana hati penutur. Ungkapan suasana hati penutur yaitu disuruh orang tua untuk menikah dengan anak orang kaya. Apabila pengungkap modalitas disuruh dihilangkan, kalimat yang diungkap penutur tersebut menimbulkan banyak makna atau bermakna tumpang tindih. Makna tersebut di antaranya, yaitu penutur mengikuti keinginan orang tua kawin dengan anak orang kaya atau mengikuti orang tua yang telah menikah dengan anak orang kaya kemudian ditinggal kabur saat usia pernikahan masih tiga bulan.

Gus Mus memilih modalitas disuruh sebagai pengungkap perintah orang tua kepada anaknya. Penutur hanya menuruti keinginan orang tuanya. Penekanan disuruh pada data (20) juga dapat dimaknai sebagai sikap taat anak kepada perintah orang tua sehingga semua perintah orang tua dituruti. Penggunaan disuruh mengindikasikan bahwa Gus Mus berdakwah mengenai kewajiban anak untuk patuh kepada orang tua. Jadi, keindahan modalitas disuruh dalam kriteria bahasa dalam karya sastra adalah mampu menyampaikan pesan atau amanat.

\section{Fungsi Optatif (Keinginan)}

Modalitas sebagai pengungkap keinginan atau fungsi optatif merupakan petunjuk dalam mengungkapkan suatu keinginan. Ungkapan ini dapat dituturkan oleh penutur kepada mitra tutur, mitra tutur kepada penutur, dan dari penutur serta mitra tutur kepada orang lain. Berikut ini data dan modalitas yang berfungsi sebagai pengungkap suasana hati keinginan atau berfungsi optatif.

(21) "Bukan ber-KB, tapi harapan saya begitu," jawab Nunik sambal tertawa, "soalnya keempat anak saya laki-laki semua. Wah repotnya setengah mati. Kalau Yu Monah berapa?" (Bisri, 2017:42)

Data (21) menunjukkan fungsi keinginan atau optatif modalitas yang ditandai pengungkap harapan. Harapan ini menunjukkan suasana hati penutur yang tidak ingin memiliki momongan lagi. Jika harapan dihilangkan, maka menyebabkan tuturan penutur bermakna seperti berharap mempunyai anak lagi sehingga bukan ber-KB yang dipilih. Adanya pengungkap modalitas harapan menunjukkan bahwa penutur benarbenar berharap tidak lagi memiliki anak.

Keinginan penutur yang diungkapkan ke dalam bentuk bahasa dengan modalitas harapan mampu mengisi fungsi estetis bahasa sastra. Fungsi estetis ini terwujud dalam keseimbangan antara bentuk, isi, dan makna yang diungkapkan modalitas. Gus Mus menjadi jembatan antara pikiran dalam dunia nyata dan dunia rekaan menggunakan modalitas. Pendayaan aspek linguistik dalam karya sastra menjadi sangat penting sebab tanpa aspek linguistik maka aspek kesastraan tidak akan mampu terungkap secara jelas, sederhana, dan menyentuh hati serta memberikan pesan bagi pembaca.

\section{Pembahasan}

Hasil penelitian ini menemukan bahwa modalitas merupakan gambaran sikap penutur terhadap suatu proposisi. Modalitas yang telah diteliti menunjukkan sikap penutur terhadap suatu peristiwa yang terjadi. Hal ini menjadi temuan awal bahwa modalitas sangat penting sebagai pengungkap sikap penutur di dalam sebuah kalimat. Modalitas juga memiliki kedudukan penting di dalam kalimat sebab ada atau tidak adanya modalitas dapat memengaruhi makna kalimat.

Penelitian ini menemukan kebaruan dalam memandang modalitas sebagai bagian dari suatu struktur kalimat. Modalitas seringkali diabaikan dan tidak disadari keberadaannya. Padahal, sikap penutur yang dituangkan ke dalam kalimat dapat dilihat melalui penggunaan modalitas. Penelitian ini memandang keberadaan modalitas sebagai bagian penting dari kalimat. Selain itu, modalitas pada temuan ini juga diintegrasikan sebagai cara mengungkap penokohan dan style Gus Mus pada antologi cerita pendek Lukisan Kaligrafi.

Penelitian ini menggunakan ilmu stilistika linguistik yang meneliti penggunaan bahasa pada karya sastra. Modalitas kalimat mengisi fungsi estetis karya sastra, yaitu kreativitas bahasa yang digunakan Gus Mus mampu mewakili sikap dan menggugah perasaan pembaca. Makna dan kadar setiap modalitas yang bervariasi mewakili sikap Gus Mus yang diungkap dengan jelas serta tidak ambigu.

Antologi cerita pendek Lukisan Kaligrafi muncul di tengah masyarakat sebagai karya yang berbeda dari karya lainnya. Tema yang disajikan Gus Mus berhubungan dengan masyarakat dan 
kehidupannya yang dikemas secara islami. Gus Mus tidak terang-terangan mencantumkan dalil Al-Qur'an dan hadis, tetapi langsung memberi contoh mengenai kehidupan sesungguhnya. Oleh sebab itu, bahasa yang digunakan dalam antologi cerita pendek Lukisan Kaligrafi ini, yaitu bahasa yang merefleksikan latar belakang masyarakat.

Modalitas kalimat dapat menjadi petunjuk gaya kepengarangan Gus Mus. Gus Mus selalu menggunakan bahasa yang sederhana, tetapi langsung menuju inti pembicaraan. Modalitas mewakili sikap Gus Mus yang tertuang dalam antologi cerita pendek Lukisan Kaligrafi. Ketika Gus Mus menyajikan cerita mengenai Ustad Bahri yang bertekad menyelesaikan satu lukisan, beliau menggunakan modalitas bertekad untuk menunjukkan sikap bertanggungjawab, memiliki kemauan keras, dan sungguh-sungguh. Bahasa yang digunakan Gus Mus sangat sederhana dan modalitas menguatkan kesederhanaan tersebut, sehingga menghasilkan pembaca bisa membaca sikap yang disajikan Gus Mus yaitu berkemauan keras dalam menjalani kehidupan.

Modalitas dalam tata kebahasaan tokoh cerpen dapat digunakan sebagai alternatif materi pembelajaran teks cerita pendek di SMA kelas XI. Penokohan dingkap melalui keberadaan modalitas kalimat dalam teks cerpen. Hal ini merupakan kebaruan modalitas kalimat dalam bidang pembelajaran sebab tidak banyak yang mengetahui modalitas yang memiliki fungsi dan kedudukan penting dalam kalimat. Modalitas kalimat dapat diidentifikasi melalui pembacaan cerita secara cermat. Apabila modalitas kalimat muncul sesuai dengan jenis-jenis modalitas yang ada, maka kemungkinan penanda tersebut adalah modalitas. Selain itu, jika dirasa penanda dalam kalimat menunjukkan sikap tokoh yang bisa dibuktikan dengan penjabaran serta kutipan percakapan atau kalimat, maka penanda tersebut juga merupakan modalitas.
Pada buku paket Bahasa Indonesia SMA/ MA/SMK/MAK kelas XI edisi revisi 2017 yang diterbitkan Kemendikbud RI, disebutkan bahwa ada enam cara untuk menggambarkan penokohan dalam cerita pendek, yaitu (1) teknik analitik langsung, (2) penggambaran fisik dan perilaku tokoh, 3) penggambaran lingkungan kehidupan tokoh, 4) penggambaran tata kebahasaan tokoh, 5) pengungkap jalan pikiran tokoh, dan 6) penggambaran oleh tokoh lain. Penggambaran penokohan difokuskan pada cara nomor empat dan lima sehingga penokohan diwujudkan dalam tata kebahasaan tokoh dan cara tokoh menggambarkan jalan pikirannya melalui modalitas.

KD yang digunakan untuk menerapkan modalitas kalimat sebagai alternatif materi teks cerpen akan yaitu KD 3.9 Menganalisis unsurunsur pembangun cerita pendek dalam buku kumpulan cerita pendek dan 4.9 Mengonstruksi cerita pendek dengan memerhatikan unsur-unsur pembangun cerita pendek. Materi yang diajarkan pada siswa, meliputi (1) pengertian modalitas, (2) macam-macam modalitas secara umum tanpa diikuti makna atau kadar, (3) langkah-langkah menentukan penokohan melalui modalitas, yaitu membaca teks cerpen, menentukan tokoh yang terlibat di dalam cerita, menentukan kutipan teks yang mengandung modalitas, (4) menyimpulkan penokohan melalui modalitas.

Tabel 1 menunjukkan contoh penerapan modalitas sebagai pengungkap penokohan cerpen. Sesuai Tabel 1, modalitas dapat digunakan sebagai alternatif mengungkapkan penokohan cerpen. Kutipan di atas diambil dari antologi cerpen Lukisan Kaligrafi karya A. Mustofa Bisri. Modalitas sebagai alternatif materi pembelajaran penokohan cerpen ini diharapkan mampu memudahkan siswa dalam menentukan penokohan pada pembelajaran cerpen. Dalam menulid cerpen, pemahaman yang baik akan membantu siswa mengembangkan karakteristik tokoh cerita.

Tabel 1. Modalitas Kalimat Sebagai Alternatif Materi Pembelajaran Teks Cerpen

\begin{tabular}{clll}
\hline Tokoh & \multicolumn{1}{c}{ Kutipan Teks } & Modalitas & \multicolumn{1}{c}{ Penokohan } \\
\hline Ustad Bahri & $\begin{array}{l}\text { Maka dia pun bertekad } \\
\text { apapun yang terjadi harus } \\
\text { ada lukisannya yang selesai }\end{array}$ & Bertekad & $\begin{array}{l}\text { Memiliki kemauan } \\
\text { keras }\end{array}$ \\
Pak Manaf & $\begin{array}{l}\text { "Pastilah seperti biasa, } \\
\text { Nasrul nderekke Mbah } \\
\text { Sidiq!" }\end{array}$ & Pastilah & Keyakinan \\
\hline
\end{tabular}




\section{PENUTUP}

Berdasarkan penelitian yang dilakukan dapat disimpulkan bahwa ciri khas dari gaya kepengarangan A. Mustofa Bisri dalam antologi cerita pendek Lukisan Kaligrafi, yaitu lugas dan luwes. Hal ini tercermin dari penggunaan modalitas sebagai pengungkap sikap Gus Mus yang dibagi menjadi empat jenis, yaitu modalitas intensional, modalitas epistemik, modalitas deontik, dan modalitas dinamik.

Setiap jenis modalitas diikuti makna dan kadar mewakili sikap Gus Mus serta mengisi fungsi estetis karya Gus Mus sendiri. Fungsi modalitas, meliputi fungsi mengubah nada, menyatakan sikap, dan pengungkap suasana hati. Fungsi tersebut menunjukkan kreativitas pemilihan berbagai aspek kebahasaan oleh Gus Mus. Diksi yang digunakan Gus Mus lebih banyak bermakna denotatif daripada konotatif sehingga menjadikan makna yang disampaikan menjadi tidak ambigu. Peng-

\section{DAFTAR PUSTAKA}

Bisri, A. M. 2017. Lukisan Kaligrafi. Jakarta: PT Kompas Media Nusantara.

Chasanah, I. N. 2006. Tradisi Sufisme dalam Karya-Karya K.H A. Mustofa Bisri. Basis. 55: 3-4.

Damayanti, T. 2012. Adverbia Penanda Modalitas dalam Novel Karya Andrea Hirata: Suatu Kajian Stuktur dan Makna. Online, http:// jurnal.unpad.ac.id/ejournal/article/view/1277

Djajasudarma, T. F. 1993. Semantik 1: Makna Leksikal dan Gramatikal. Bandung: PT Refika Aditama.

Eryon. 2011. Satu Tinjauan Deskripsi tentang Modalitas Bahasa Inggris dan Bahasa Indone- gunaan modalitas untuk mencapai keindahan tersebut menjadi style dan ciri khusus Gus Mus dalam menuangkan ide serta gagasan dalam karyanya, yaitu antologi cerita pendek Lukisan Kaligrafi.

Modalitas dapat digunakan sebagai alternatif materi pembelajaran teks cerita pendek untuk SMA difokuskan pada penokohan cerita pendek. Modalitas sebagai alternatif materi pembelajaran penokohan cerpen ini diharapkan mampu memudahkan siswa dalam menentukan penokohan cerpen atau mengembangkan karakteristik tokoh.

\section{UCAPAN TERIMA KASIH}

Penulis menyampaikan ucapan terima kasih kepada mitra bestari (reviewers) yang telah memberikan saran, kritik, dan rekomendasi untuk perbaikan artikel ini.

nesia. Jurnal Linguistika, 2(2): 43-61.

Jakfar Is, M. 2016. Analisis Kata Keterangan Modalitas dalam Kolom OpiniHarian Serambi Indonesia. JIPSA, 16(25): 1-8.

Prihantoro, E. dan D. R. Fitriani. 2015. Modalitas dan Teks Media Berita Online. Prosiding. Seminar PESAT (Psikologi, Ekonomi, Sastra, Arsitektur \&Teknik Sipil), Depok 20-21 Oktober 2015

Priyatni, E. T. 2010. Membaca Sastra dengan Ancangan Literasi Kritis. Jakarta: Bumi Aksara.

Sutedi, D. 2004. Dasar-dasar Linguistik Bahasa Jepang. Bandung: Humaniora Utama Press. 